\title{
ARTIGOS
}

\section{SCHISTOSOMA MANSONI IN MICE: MODULATION OF GRANULOMATOUS RESPONSE AFTER REINFECTION AND CHEMOTHERAPEUTIC TREATMENT}

\author{
Paulo Marcos Z. Coelho, Pedro Raso, Rômulo Teixeira de Mello and Nivaldo \\ H. Toppa
}

\begin{abstract}
Mice previousty infected with Schistosoma mansoni, and cured by specific treatment $(400 \mathrm{mg} / \mathrm{kg}$ oxamniquine, $p . o$.) in the chronic phase of the disease, were reinfected 20 days after treatment to assess their capacity formodulation of the granulomatous response. Histopathologic examination of the animals' liver, at 60 days after reinfection, evidenced the presence of typical granulomas of the chronic phase in most animals. This infer that the capacity for modulation of the granulomatous response had been maintained, thus preventing a new acute phase of the disease. Conversely, a group of previously infected mice, untreated and submitted to reinfection, showed reactivation of the granulomatous response in 50\% of the animals. The possible implications of these findings in human schistosomiasis mansoni are discussed.
\end{abstract}

Key-words: Schistosoma mansoni. Granuloma. Chemotherapeutic treatment. Modulation of granulomatous response.

In 1964 Andrade \& Warren ${ }^{4}$ demonstrated that a decrease in the size of granulomas formed around Schistosoma mansoni eggs occurs at the chronic phase of the disease, as well as alterations in the cellular and non-cellular constituents which participate in this inflammatory process. This phenomenon has been corroborated by several other authors, as can be seen in Boros' review' ${ }^{7}$. This state of immune tolerance in relation to the antigens excreted by eggs represents a control over the immunopathological response, and this phenomenon is called modulation of the granulomatous response. Colley et al. ${ }^{12}$, showed a higher blastogenic response induced by soluble egg antigens in individuals with severe clinical forms of schistosomiasis. Conversely, the absence of the granulomatous reactivity in immunodepressed animals showed aggravation of the pathologic process 91117242528 .

Considering that this modulation of the

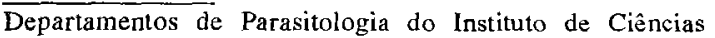
Biológicas, de Análises Clínicas e Toxicológicas da Facuidade de Farmácia e de Anatomia Patológica da Faculdade de Medicina, Universidade Federal de Minas Gerais, Belo Horizonte, MG; Universidade Federal de Ouro Preto, Ouro Preto, MG.

This work was supported in part by CNPq, FAPEMIG, and FINEP, Brazil, and by WHO, Switzerland.

Address to: Prof. Paulo Marcos Z. Coelho. Depto. de Parasitologia/ICB/UFMG, Caixa Postal 486, 30161-970 Belo Horizonte, MG.

Recebido para publicação em 06/01/94.
}

granulomatous response is favorable to the host, and that millions of people have been submitted to treatment, a large number of them being cured, it is important to determine whether modulation of the immunopathology remains after cure, since many of the individuals treated and cured will certainly be reinfected. On the other hand, it is a matter of interest to know whether reinfection of the host bearing active schistosomiasis can modify this state of immune tolerance due to other immunological stimuli in consequence of cercarial penetration, migration of the parasites from the skin to the lungs, and from the lungs to the portal system, leading to an increase of the initial population, as well as of the number of eggs in the tissues.

This work aims at studying in mice whether the modulation of the granulomatous process around eggs remains after cure and, on the other hand, if reinfection can alter this state of control in untreated animals, as far as the granulomatous response is concerned.

\section{MATERIALS AND METHODS}

Female outbred albino mice were used in these experiments. The Schistosoma mansoni strain utilized was the LE strain (isolated from a patient in Belo Horizonte, MG, Brazil, and kept for more 
Coelho PMZ, Raso P, Mello RT, Toppa NH. Schisto soma mansoni in mice: modulation of granulomatous response after reinfection and chematherapeutic treatment. Revista da Sociedade Brasileira de Medicina Tropical 27:119125, jul-set, 1994.

than 30 years at the laboratories of the Schistosomiasis Research Unit, Federal University of Minas Gerais, Brazil, the intermediate and definitive hosts being Biomphalaria glabrata and hamster, respectively). Mice were infected initially with $15 \mathrm{~S}$. mansoni cercariae (LE strain), by subcutaneous route, excep group $\mathrm{V}$.

The animals were then divided into five groups (the uninfected group being kept as control of reinfection), and submitted to the following procedures:

Group I $(\mathbf{n}=11)$. The mice were previously infected and treated with $400 \mathrm{mg} / \mathrm{kg}$ oxamniquine, single dose, oral route, at 100 days after infection. They were reinfected with 20 cercariae, by subcutaneous route, at 20 days after treatment, and sacrificed at 60 days after reinfection.

Group II $(\mathbf{n}=\mathbf{8})$. The animals previously infected were submitted to treatment with $400 \mathrm{mg}$ / $\mathrm{kg}$ oxamniquine, oral route, at 100 days after infection, and sacrificed at the same date of group $I$, that is, at 60 days after reinfection of groups I and III.

Group III $(n=24)$. The animals previously infected were reinfected and sacrificed at the same dates of group I.

Group IV $(n=11)$. The animals bearing the initial infection were sacrificed together with all the other groups, i.e., at $\mathbf{1 8 0}$ days after infection or 60 days after reinfection of groups I and III.

Group V ( $\mathrm{n}=19)$. This group (without previous infection) was submitted to infection with 20 cercariae by subcutaneous route, at the same date established for reinfection of groups I and III, and sacrificed at 60 days after infection.

The animals were killed by cervical fracture, and their livers preserved in $10 \%$ buffered formalin. A group of 10 treated mice was perfused for worms, at 30 days after chemotherapy. No worms could be found, thus confirming the efficacy of the treatment.

The preserved livers were sliced into small bits of $3.0 \mathrm{~mm}$ of thickness each, and soaked in parafin. The slices of $5 \mu \mathrm{m}$ thickness so obtained were stained with hematoxylin and eosin.

Only the diameters of the granulomas at the necrotic-exudative, exudative and productive phases were meacured. The other ones (granulomas in process of cure by fibrosis) were not considered.
The average of the diameter size was determined by the mean between the smaller and largest measurements of the diameters passing through the miracidium inside the egg, which was identified by the eosinophilic staining. Therefore, only recent granulomas were examined with a splitting eyepiece (10X, Ernest-Leitz, Wetzlar, Germany) adapted to a Zeiss microscope.

Statistical analysis. Analysis of variance was used to detect differences among the mean granuloma measurements recorded for groups I, III, IV and V. Group II which presented no recent granulomas, but only granulomas that were already cured by fibrosis, was not taken into account for purposes of analysis.

\section{RESULTS}

\section{Histopathological description of the animals'liver used in this experiment:}

Group I (treated and reinfected). Most animals presented granulomas at two different evolutive phases: a) some at the recent exudative phase, probably resulting from reinfection; b) others at the repairable phase or in process of cure by fibrosis, certainly derived from primo infection. These granulomas were found to be markedly smaller than the others at the exudative phase.

For the most part, the granulomas were found at the portal tracts; sometimes they were confluent and, in some animals, they were permeated by intense inflammatory infiltrate. This was responsible for cuffing on the other portal tracts. Moreover, ductal proliferation associated to accentuated regressive phenomena of the epithelial cells with acidophilic homogeneous cytoplasm and nuclei that were either picnotic or absent could be seen.

The hepatocytes showed regressive phenomena and recent necrotic areas of different sizes, with scarce inflammatory reaction, if any, as well as older necrotic areas, partially substituted by young conjunctive tissue. Furthermore, an intense polyploidy could be seen.

Both the portal macrophages and Kupffer cells carried a large amount of schistosome pigment. The Kupffer cells were found to be hypertrophic and 
Coelho PMZ, Raso P, Mello RT, Toppa NH. Schistosoma mansoni in mice: modulation of granulomatous response after reinfection and chemotherapeutic treatment. Revista da Sociedade Brasileira de Medicina Tropical 27:119125, jul-set, 1994.

hyperplastic. Intact and stunt worms could also be observed inside the portal branches, with little or no inflammatory reaction around them.

Group II (treated and non-reinfected). In this group, nearly all granulomas were coetaneous, at the same evolutive phase of cure by fibrosis, few of them totally hyalinized. There was discrete inflammatory infiltrate in the portal tracts. In spite of their presence, the degenerative phenomena of cells in the ductal epithelium were not so as intense as those observed in group I. Moreover, necrosis of the hepatocytes was not so as frequent and intense as that detected in group I. Small amounts of schistosome pigment were also seen inside the portal macrophages and Kupffer cells.

Group II (infected and reinfected). This group was composed of numerous granulomas, which were detected both at exudative phase (with or without necrosis) and at the phase of cure by fibrosis. Granulomas cured by fibrosis were found to be predominant. The most important difference between this group and group I was the intensity of the diffuse exudative phenomena that occurred at the portal hepatic spaces, and sometimes in the inner part of the hepatic lobes. Hepatic necrosis showed less intensity and extension. Lesions caused by dead worms were unfrequent. There was a clear predominance of primo infection over the recent ones, due to a larger number of granulomas and cure by fibrosis.

Group IV (control of the chronic phase). Granulomas relating to this group were coetaneous, at the phase of cure by fibrosis; very few of them were at the exudative or productive-exudative phases. Moderate inflammatory infiltrate was also found in the portal ducts, as well as a discrete hyperplasia in the hepatic ducts. The hepatocytes were found to be polyploid, and the regressive phenomena, although being clearly detected, were not as intense as those previously observed.

Group V (control of the acute phase). This group differred from the others because it presented a larger number of granulomas. These granulomas were larger-sized and more confluent, and were found to be at the exudative and necrotic-exudative phases, very few of them being at the phase of cure by fibrosis. The inflammatory portal infiltrate was found to be independent of the granulomatous lesion, and less intensive as it. A point of interest was constituted by the extensive areas of necrosis by coagulation of the hepatocytes, which were generally near to the site of egglaying, and involved by an accentuated inflammatory exudate.

Assessment of the average size of the hepatic granulomas at the productive phase in all the mice from different groups:

The analysis of variance was used to determine statistically significant differences among the mean diameters of recent granulomas from different groups ( $p<0.01$ ). In this manner, group IV (pattern of the chronic phase) showed statistically significant differences in relation to groups III (reinfected at the chronic phase) and V (control of the acute phase) (Tables 1 and 2).

On the other hand, groups $V$ (control of the acute phase) and III (reinfected at the chronic phase) showed statistically significant differences, when compared with the other groups. Conversely, groups I (cured at the chronic phase and reinfected) and IV (control of the chronic phase) did not show significant differences among themselves in connection with the average size of the granulomas (Table 1). The

Table 1- Mean diameters of liver granulomas in different groups of mice with schistosomiasis mansoni.

\begin{tabular}{ccc}
\hline Groups & $\begin{array}{c}\text { Number } \\
\text { of } \\
\text { mice }\end{array}$ & $\begin{array}{c}\text { Mean and standard error } \\
\text { deviation of } \\
\text { granuloma diameters }\end{array}$ \\
\hline I * & 11 & $222.96 \pm 22.43$ \\
II ** & 8 & $142.00 \pm 13.31$ \\
III * & 24 & $237.77 \pm 22.26$ \\
IV * & 11 & $220.97 \pm 17.09$ \\
V * & 19 & $275.51 \pm 27.28$ \\
\hline
\end{tabular}

$I=$ infected, treated with oxamniquine and reinfected

II $=$ infected and treated

III $=$ infected and reinfected

IV $=$ infected (primo infection)

$\mathrm{V}=$ infected at the same date of reinfection of the other groups (control of reifection)

* granulomas at the productive phase

** granulomas at the phase of cure by fibrosis 
Coelho PMZ, Raso P, Mello RT, Toppa NH. Schistosoma mansoni in mice: modulation of granulomatous response after reinfection and chemotherapeutic treatment. Revista da Sociedade Brasileira de Medicina Tropical 27:119125, jul-set, 1994.

Table 2 - Distribution of mice from Groups I, III and V, related to mean diameter of granulomas, in connection with the mean diameter \pm standard error deviation of the granulomas of Group IV.

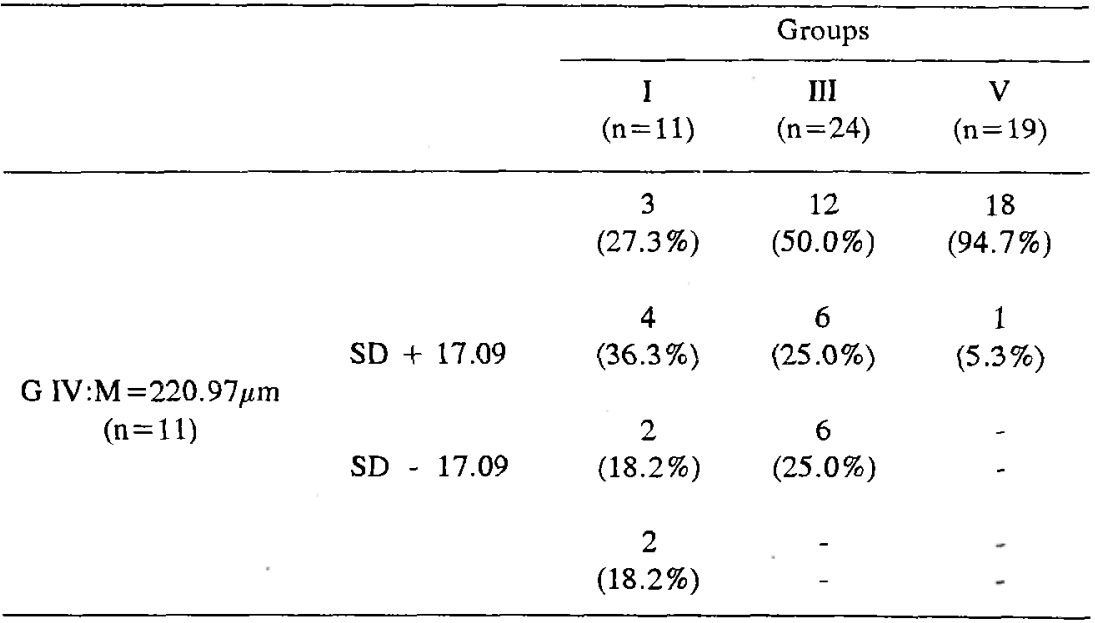

$I=$ infected, treated with oxamniquine and reinfected

III $=$ infected and reinfected

IV = infected (primo infection) - pattern of the chronic phase

$\mathrm{V}=$ infected at the same date of the other groups (control of reifection)

results of the mean diameters of the granulomas at the productive phase in different groups (group II excepted, because it comprises treated and unchallenged animals, therefore without recent granulomas), in relation to the typical granulomas of the chronic phase (group IV), represented by the mean and standard error deviation (- and + ), are shown in Table 2.

\section{DISCUSSION}

The approach of the present study is based on the fact that schistosomiasis presents two different phases, i.e., the acute phase and the chronic one. The former is represented by an intensive inflammatory reactivity around eggs, causing extensive lesions, whereas at the chronic phase the host's organism modulates or regulates this response, resulting in granuloma formation of minor dimensions, and composed of peculiar cellular infiltrate, causing lesser injury to the tissues ${ }^{48}$. The absence of this capacity for modulation or control of the immune cellular response can be one of the reasons for the manifestation of severe anatomoclinical forms of the disease ${ }^{12}$. The results described here allow us to affirm that reinfection of mice did not bring about the appearance of a new acute phase for most animals. This significant number of animals presented typical granulomas of the chronic phase. The capacity for modulation of the granulomatous response was maintained in most cured animals ( 8 out of II mice in group I Table 2).

In 1982 Andrade \& Brito $^{3}$ verified that animals treated at the acute phase of the disease ( 70 days), therefore without developing the mechanism of responsiveness modulation yet, presented a new acute phase when reinfected. Considering that in Brazil millions of people that have been treated and cured (most of them at the chronic phase) are still living in endemic areas, the present results allow a certain optimism in relation to the severity of the immunopathology resulting from reinfection. Data from different epidemiological studies corroborate this supposition inasmuch as populations of treated and cured individuals, living in endemic areas, showed a marked reversion of the hepatosplenic forms of schistosomiasis ${ }^{61516202225}$. 
Coelho PMZ, Raso P, Mello RT, Toppa NH. Schistosoma mansoni in mice: modulation of granulomatous response after reinfection and chemotherapeutic treatment. Revista da Sociedade Brasileira de Medicina Tropical 27:119125, jul-set, 1994.

Although Gazzinelli et al. ${ }^{19}$, demonstrated that individuals treated with chemotherapy two years ago, living in non-endemic areas, seemed to have lost their capacity for modulation of the granulomatous inflammatory response, it is worth to emphasize that the process of transmission of the disease persists in endemic areas submitted to mass treatment. In this manner, it is of fundamental importance to proceed the evaluation of the persistence of the capacity for modulation of the granulomatous inflammatory response immediately after treatment, in order to prevent the possibility of new acute phases of the disease resulting from reinfection.

The present results showing the permanence of the capacity for modulation of the granulomatous response in most of the treated and reinfected mice, added to results obtained by Andrade \& Brito ${ }^{3}$ and Bezerra et al. ${ }^{5}$ demonstrating that the acquired immunity in mice remains after parasitological cure for a certain period of time, corroborate the pertinent observations of the conference read by Prata $^{26}$ on Schistosomiasis, that summarized the results obtained by him and other investigators demonstrating that the majority of the individuals treated and cured, but living in endemic areas, posteriorly were found to be reinfected with a lower worm burden, showing also lower morbidity.

It is also a point of interest in this study the important observation that reinfection can alter the immune regulation state of the granuloma, in significant numbers, in mice carrying a primary chronic infection (12 out of 24 mice in group III Table 2).

Furthermore, the results of the present study strengthen the need to consider the differential responsiveness in the immunopathological process. Thus, the use of outbred mice (without the homogeneous genetic pattern that occurs in well defined breeds) in the present experiments allowed the identification of diversity in immunopathological response. For example, in an experiment with challenged animals previously cured by specific chemotherapy, preservation of the capacity of granulomatous response modulation could be observed in various, but never in all, individuals. On the other hand, the alteration in the control of immunopathology, that can be observed in the group comprising untreated animals at the chronic phase of the disease and later reinfected (group III), al though occurring in 12 animals (50\%), shows that the remaining 12 mice were able to keep modulation of the response (Table 2).

Other works dealing with populations from endemic areas show a lower frequency of severe cases of the disease in the African race 101423252730 . Moreover, the influence of blood groups on the determinism of severe anatomo-clinical forms bears further evidence of the genetic factor in the pathogeny of the disease ${ }^{25}$. The AI and B5 antigens from the histocompatibility system have been also correlated with hepatosplenic forms of the disease ${ }^{12}$. To this argumentation, we should add the occurrence of a higher incidence of hepatosplenic forms, in individuals pertaining to the same familiar group ${ }^{13}$ 2129 . It has also been demonstrated the racial influence on the modulation of the immunopathological response, as well as the appearance of hepatosplenic forms of the disease in mice ${ }^{18}$. Taking all these considerations into account, the role of the genetic factor in the immunopathology of schistosomiasis seems to be clear. Our results, showing the individual variability of the modulation capacity in outbred mice, and corroborating the results obtained by Fanning et al. ${ }^{18}$ reinforce that viewpoint. These conclusions seem to be more relevant when they are extrapolated to the epidemiological context of human schistosomiasis, considering that in some countries such as Brazil an intense interracial crossing occurred in the past, and is occuring yet.

Finally, the maintenance of the modulation capacity for immunopathological response in the majority of the cured and reinfected animals reinforces some epidemiological findings showing that chemotherapeutic mass treatment leads to a decrease in the severe forms of the disease in areas submitted to treatment.

\section{RESUMO}

Para verificar a capacidade de modulação da resposta granulomatosa na esquistossomose murina, após cura quimioterápica, camundongos previamente infectados foram curados com oxamniquina $(400 \mathrm{mg} / \mathrm{kg}$, p.o.) e reinfectados 20 dias após tratamento. $O$ exame histopatológico do fígado dos animais, aos 60 dias após reinfecção, mostrou, na maioria deles, a presença de granulomas na fase produtiva, típicos da fase crônica da 
Coelho PMZ, Raso P, Mello RT, Torppa NH. Schistosoma mansoni in mice: modulation of granulomatous response after reinfection and chemotherapeutic treatment. Revista da Sociedade Brasileira de Medicina Tropical 27:119125, jul-set, 1994.

doença, permitindo a inferência de que a capacidade de modulação da resposta granulomatosa foi mantida, prevenindo assim uma outra fase aguda da doença. Por outro lado, um grupo de camundongos previamente infectados e submetidos a reinfecção mostrou a reagudização da resposta granulomatosa em $50 \%$ dos animais. As possiveis implicações destes achados na esquistossomose mansoni humana são discutidas.

Palavras chaves: Sçistosoma mansoni. Granuloma. Tratamento quimioterápico. Modulação da resposta granulomatosa.

\section{ACKNOWLEDGMENTS}

To Mrs. Vera de Paula Ribeiro for translating the manuscript. To Mr. Alberto G. Santos, Alice Neni F. Balzuweit and Zenir de Souza for technical assistance.

\section{REFERENCES}

1. Abaza H, Asser L, Sawy M, Wasfy S, Montaser L, Shaltout A. HLA antigen in schistosomal hepatic fibrosis patients with haematemesis. Tissue Antigens 26:307-309, 1985.

2. Abdel-Salam E, Ishaac C, Mahmoud AA. Histocompatibility -linked susceptibility for hepatosplenomegaly in human schistosomiasis mansoni. Journal of Immunology 123:1829-1831, 1979.

3. Andrade ZA, Britto PA. Curative chemotherapy and resistance to reinfection in murine schistosomiasis. The American Journal of Tropical Medicine and Hygiene 31:116-121, 1982.

4. Andrade ZA, Warren KS. Mild prolonged schistosomiasis in mice, alterations in host response with time and the development of portal fibrosis. Transactions of the Royal Society of Tropical Medicine and Hygiene 58:53-57, 1964.

5. Bezerra FSM, Coelho PMZ, Tavares CAP. Schistosoma mansoni: protective immunity in mice cured by chemotherapy at the chronic phase of the disease. Revista do Instituto de Medicina Tropical de São Paulo 35:337-344, 1993.

6. Bina JC, Prata A. A regressão da hepatoesplenomegalia pelo tratamento específico da esquistossomose. Revista da Sociedade Brasileira de Medicina Tropical 16:213-218, 1983.

7. Boros DL. Immunopathology of Schistosoma mansoni infection. Clinical Microbiological Reviews 2:250-269, 1989.

8. Boros DL, Warren KS. Delayed hypersensitivity granuloma formation and dermal reaction induced and elicited by a soluble factor isolated from Schistosoma mansoni eggs. Journal of Experimental Medicine 132:488-539, 1970.

9. Buchanan RD, Fine DP, Colley DG. Schistosoma mansoni infection in mice depleted of thymus dependent lymphocytes. II - Pathology and altered pathogenesis. American Journal of Pathology 71:207214, 1973.

10. Cardoso WA. Esquistossomose mansoni no negro. Medicina, Cirurgia e Farmácia 202:89-95, 1953.

11. Carter CE, Colley DG. Partial purification of Schistosoma mansoni soluble egg antigen with ConA- Sepharose chromatography. Journal of Immunology 122:2204-2209, 1979.

12. Colley DG, Garcia AA, Lambertucei JR, Parra JC, Katz N, Gazzinelli G. Immune response during human schistosomiasis. XII - Differential responsiveness in patients with hepatosplenic disease. American Journal of Tropical Medicine and Hygiene 35:793-802, 1986.

13. Conceição MJ, Coura JR. Ocorrência familiar da esplenomegalia esquistossomótica em uma área rural de Minas Gerais. Revista da Sociedade Brasileira de Medicina Tropical 13:17-20, 1980.

14. Coura JR. Morbidade da esquistossomose no Brasil. Tese de Doutorado, Universidade Federal do Rio de Janeiro, Rio de Janeiro, RJ, 1979.

15. Coutinho A, Domingues ALC. Specific treatment of advanced schistosomiasis liver disease in man: favorable results. Memórias do Instituto Oswaldo Cruz 82:335-340, 1987.

16. Dietze R, Prata AR. Rate of reversion of hepatosplenic schistosomiasis after specific therapy. Revista da Sociedade de Medicina Tropical 19:6973, 1988.

17. Doenhoff MJ, Musslam R, Bain J, McGregor A. Schistosoma mansoni infection in $\mathrm{T}$ cell deprimed mice and the amelioration effect of administering homologous chronic infection serum. I Pathogenesis. The American Journal of Tropical Medicine and Hygiene 28:260-273, 1979.

18. Fanning MM, Peters PA, Davis RS, Kazura JW, Mahmoud AA. Immunopathology of murine infection with Schistosoma mansoni: relationship of genetic background to hepatosplenic disease and modulation. Journal of Infectious Diseases 144:148-153, 1981.

19. Gazzinelli G, Viana IRC, Bahia-Oliveira LMG, Silveira AMS, Queiroz CC, Carvalho OS, Massara CL, Fraga LAO, Colley DG, Correa-Oliveira R. Immunological profiles of patients from endemic areas infected with Schistosoma mansoni. In: Abstracts of III International Symposium on Schistosomiasis - National Meeting on 
Coelho PMZ, Raso P, Mello RT, Toppa NH. Schistesoma mansoni in mice: modulation of granulomatous response after reinfection and chemotherapeutic treatment. Revista da Sociedade Brasileira de Medicina Tropical 27:119. 125, jul-set, 1994.

Schistosomiasis, Recife, PE. Memórias do Instituto Oswaldo Cruz 87 (suppl IV):139-142, 1992.

20. Katz N. Experiências com quimioterapia em grande escala no controle da esquistossomose no Brasil. Revista do Instituto de Medicina Tropical de São Paulo 22:40-51, 1980.

21. Kloetzel K. A síndrome hepato-esplênica na esquistossomose mansônica. Considerações sobre a incidência familiar. Revista Brasileira de Medicina 15:263-265, 1958.

22. Kloetzel K. Selective chemotherapy for schistosomiasis mansoni. Transactions of the Royal Society of Tropical Medicine and Hygiene 68:344, 1974.

23. Pereira DMSM. Sistemas HLA, ABO, Rh e características raciais em pacientes com hepatoesplenomegalia esquistossomótica. Tese de Mestrado. Brasilia, DF, 1979.

24. Phillips SM, Diconza JJ, Gold, JA, Reid WA. Schistosomiasis in congenitally athymic mouse. I Thymic dependence of eosinophilia granuloma formation and post inorbidity. Joumal of Immunology 118:594-599, 1977.

25. Prata AR. Esquistossomose mansoni: fatores determinantes das formas anátomo-clínicas $\mathrm{e}$ evolução da doença. In: Castro L, Rocha PRS, Cunha AS (eds) Tópicos em Gastroenterologia 2nd edition. Medsi - Rio de Janeiro, RJ p. 3-12, 1991.

26. Prata AR. Avanços na metodologia e estratégias do controle da esquistossomose. In: Abstracts of IV International Symposium on Schistosomiasis. Rio de Janeiro p.3, 1993.

27. Prata AR, Schroeder SA. Comparison of whites and negroes infected with Schistosoma mansoni in hyperendemic area. Gazeta Médica da Bahia 67:9398, 1967.

28. Raso, P, Rocha OA, Pereira LH, Tafuri, WL. Efeito da timectomia neonatal na esquistossomose mansoni experimental. Revista das Sociedade Brasileira de Medicina Tropical 16:112-121, 1983.

29. Tavares-Neto J, Prata AR. Family occurrence of schistosomal hepatosplenomegaly and maternal effects. Revista da Sociedade Brasileira de Medicina Tropical 22:13-18,1989.

30. Tavares-Neto J, Prata AR. Forma hepatoesplênica da esquistossomose mansônica, em relação à composição racial e nível socio-econômico, em Catolândia-Bahia. Revista da Sociedade Revista da Sociedade Brasileira de Medicina Tropical 23:9-14, 1990. 